\title{
Iwona Zamkowska
}

The Kazimierz Pulaski University

of Technology and Humanities, ul. J. Malczewskiego 29, 26-600 Radom, Poland

\section{The New Consensus Movement and Its Role in Overcoming the Controversy and Conflict over the Place of Religion in the U.S. Educational System}

\begin{abstract}
1. Introduction
The mid-1980s saw a decisive shift in the approach to religious liberty in the American educational system. The shift was the fruit of a concerted effort of numerous influential bodies - both political and religious - which subsequently led to the emergence of the New Consensus on teaching about religion and religious liberty in public schools. The consensus came as a direct response to the confusion, controversy and conflict characterizing the "religion and school debate" at that time. The debate would regularly mark its presence in courtrooms, direct-mail campaigns, local school board elections, and national politics (Murray 2008:94). It was also considered to be an important part of a conflict raging in a broader society over the role of religion in public life, frequently referred to as "culture wars" (Murray 2008:168).
\end{abstract}


Although the term "culture wars" is relatively recent, the phenomenon has a long-standing tradition in American public square. Over the twentieth century, however, major battles of this war were fought in all areas of the school curriculum between secular and religious interpretations of the world. The controversies seem to have occurred with great frequency and embraced a wide range of topics (Nord and Haynes 1998:4-5). Since these controversies were heavily regulated by the law, public school teachers and principals, school board directors, and other school officials were left vulnerable to legal liability. The situation was further complicated by the fact that religious issues in public schools were governed by multiple sources of law, ranging from federal and state constitutional law to school board policies. Even the pertinent constitutional clauses that govern the most common disputes involving religion in public schools: the Establishment, Free Exercise, and Free Speech Clauses of the United States Constitution's First Amendment, posed a difficulty for many schools regarding how to permit religious liberty without endorsing religion (Lofaso 2009:13).

The confusion was largely fuelled by the misunderstanding and misapplication of the Supreme Court's decisions of the early 1960's, striking down state-sponsored prayer and devotional Bible reading in public schools. Considering the political rhetoric surrounding the Supreme Court's decisions, many school administrators became convinced that religion and religious expression had no place in public schools (Murray 2008:94). Withdrawn from the school system, religion also disappeared from school textbooks, as many educational publishers - fearing controversy - started to ignore the role of religion in history and other subjects. Outraged by what became to be labeled as "kicking religion out of school," many religious conservatives took the absence of religion to imply hostility to religion. This fuelled the culture wars even more and driven many students out of the state schools to the private educational sector (Nord and Haynes 1998:1-2).

The mid-1980s, however, witnessed a growing concern over the failure to address the issue of religion in the system of education. Ongoing bitter culture wars gave rise to an increasing awareness 
among both politicians and educators of the need to treat religion seriously and to fundamentally transform the public school status quo from a "battleground" to a "common ground."

The following article will examine the key factors that contributed to this awareness, such as the results of textbook studies and periodic reports from curriculum institutions as well as the challenge of religious pluralism and the passage of two important documents: the Equal Access Act (1984) and The Williamsburg Charter (Haynes 2001, Appendix B). The latter, over a period of time, paved the way for the rise of the New Consensus on teaching about religion and religious liberty in the public schools. The major ideals and principles of the New Consensus will be outlined in the subsequent part of the article, followed by a brief description of the official guides devised to facilitate the implementation of the New Consensus ideals in public schools.

2. The impact of textbook studies and periodic reports from curriculum institutions

Among the factors credited for fostering the need to treat religion seriously were alarming textbook studies. The results of one of the studies conducted by Dr. Paul Vitz, Professor of Psychology at New York University, and reported in Censorship: Evidence of Bias in Our Children's Textbooks (Grudem 1986:1), seemed to provide an accurate illustration of the scope of the problem. The report is based on a government-funded survey that examined the way religion and traditional values were represented in 90 widely used reading and social studies textbooks in United States schools. The findings showed that religion, traditional family values, and conservative political and economic positions had been reliably excluded from children's textbooks (Grudem 1986:4).

Apart from textbook studies, another potent source testifying to the complete negligence of religion-related content in the school curriculum were periodic reports from curriculum institutions, most notably the Association for Supervision and Curriculum Development (ASCD) and the National Council for the Social Studies (NCSS). The 
statements issued by these institutions deprecated the absence of religion in the curriculum and called for inclusion of such information in curricular materials and in teacher education (ASCD Panel on Religion in the Curriculum, A. for S. and C.D.,1987; NCSS, 1998).

2. The challenge of religious pluralism

The ignorance of religious matters in the school system in general, and in the curriculum in particular, was seen by many as standing in great contrast with the pervasive religiosity and exploding religious pluralism of the American nation. The challenges of pluralism were particularly evident in public schools where many different religions were represented (Nord and Haynes 1998:34-35).

In the face of increasing religious diversification of students, the necessity to address the challenge became even more pressing. The position statement of the above-mentioned NCSS report strongly emphasizes that knowledge about religions is a characteristic of an educated person and "absolutely necessary for understanding and living in a world of diversity." It is "knowledge of religious differences and the role of religion in the contemporary world," argue the authors of the report, which "can help promote understanding and alleviate prejudice" (NCSS 1998).

3. Political pressure and the passage of the Equal Access Act (1984) and the Williamsburg Charter (1988)

It was against this backdrop that politicians, followed by some major religious and educational organizations, determined to take some decisive steps to address the problem of public schools as "religionfree zones." On the political level this led to the passage of a number of acts, such as the Equal Access Act (1984) and the Williamsburg Charter (Haynes 2001: Appendix B). The former was the landmark United States federal law that regulated one of the controversial issues concerning student's religious expression, namely the use of school facilities by student non-curriculum-related clubs. Under the provision of the original Act (1984) and its revised version (1998), every public secondary school which receives federal financial assistance and 
which has a limited open forum (i.e. allows one or more students noncurriculum-related clubs to meet on its premises during noninstructional time) is obliged to allow its students to use school facilities to perform their religious activities (such as a prayer service, Bible reading or other worship exercise) on the same terms as other comparable student groups. The act represented a major breakthrough in the effort to allow for student religious expression in public schools. Thus, it opened the forum for other controversies over the place of religion in public education to be formally settled, which will be discussed in the subsequent part of the article.

The latter document, the Williamsburg Charter (Haynes 2001: Appendix B), signed in 1988 by 200 national leaders, including representatives of America's major faiths, political leaders, and scholars, rededicated American citizens to the principles of religious freedom guaranteed by the First Amendment. In the face of controversy over religious issues, the Charter calls for a critical reappraisal of the course and consequences of such controversy, and the commitment to conducting the debate of the nation's deep differences with civility and respect. The Charter is among the foundational documents that demanded the acknowledgment of religious liberty clauses in the public square, and more specifically, articulated the principles that a peaceful dispute on religious differences should abide by. Its principles of rights, responsibilities, and respect, known as "Three Rs," later became the motto of a number of educational programs.

4. A New Consensus on teaching about religion

Although the Equal Access Act significantly contributed to opening the door to student religious expression, it left unanswered many other questions about the religious liberty rights of students. The Act did not address the issue of religion in the curriculum either. In an effort to advance the process of going beyond the controversy, confusion and fights of the past, a coalition of diverse religious and educational groups decided to join their efforts to develop guidelines regarding some of these unresolved issues. From their cooperation emerged a 
consensus on teaching about religion, known as a New Consensus. It was reached by a broad range of views and was based on the agreement that "ignoring religion was neither educationally sound nor consistent with the First Amendment" (Haynes 2001:5). Its vision of the role of religion and religious liberty in public schools is encapsulated in Principle IV of "Religious Liberty, Public Education, and the Future of American Democracy: A Statement of Principles" published in 1995. The principle restates the civic framework of the religious-liberty clauses of the First Amendment as applied to public education, defining religious liberty in public schools as follows:

Public schools may not inculcate nor inhibit religion. They must be places where religion and religious conviction are treated with fairness and respect.

Public schools uphold the First Amendment when they protect the religious liberty rights of students of all faiths or none. Schools demonstrate fairness when they ensure that the curriculum includes study about religion, where appropriate, as an important part of a complete education (Haynes 2001:12).

First of all, the definition acknowledges the constitutionality of religious education in public schools, as well as its vitality for a complete education. Secondly, it puts emphasis on the fact that the only constitutionally permissible form of religious education is "teaching about religion." Finally, it specifies general principles of religious education, like the ones of fairness and respect.

The specific guidelines how to properly include the study about religion in the school curriculum are outlined in the following pamphlets: Religion in the Public School Curriculum: Questions and Answers, Religious Holidays in the Public Schools, and Equal Access and the Public Schools: Questions and Answers. The first of the pamphlets (Haynes 2001: 87-92) defines "teaching about religion" as distinguished from religious indoctrination. Namely, it states that the school approach to religion should be academic, i.e. based on exposing students to a diversity of religious views, rather than devotional, i.e. one that involves practicing, imposing, promoting or denigrating any particular belief. The document also defines the place of the study of religion in the public school curriculum. It recommends the inclusion of the study of religion "wherever it 
naturally arises" (Haynes 2001: 91), i.e. at the secondary level: in social studies, literature and the arts; and at the primary level: in discussions of the family and community life, and in instruction about festivals and different cultures. The document states that while teaching values can be allowed in the classroom, it cannot involve invoking religious authority by the teachers; nor can a particular religious perspective on moral issues be presented with adopting, sponsoring or denigrating one view against the other.

Religious Holidays in the Public Schools (Haynes 2001:103-112) outlines the place and the manner of teaching about religious holidays as consistent with the New Consensus definition of religious liberty. Among the issues discussed in the booklet is the use of religious symbols and music in public schools, as well as the problem of exemption from classes on religious holidays and from the participation in religious holidays. Also included are guidelines for developing school policies about the treatment of religious holidays in the curricula, tips for planning religious holidays in public schools and a brief legal analysis on religious holidays and public schools.

Equal Access and the Public Schools: Questions and Answers (Haynes 2001:106-109) clarifies the major provisions of the Equal Access Act and their application to specific school situations as interpreted by the U.S. Supreme Court. The pamphlet stresses the equality and consistency in guaranteeing access to school facilities among all eligible student groups, most assuredly Bible study programs, or other religiously focused clubs. It also states that the school can deny access to school facilities if the group's meetings materially and substantially interfere with orderly conduct, or if the group refuses to comply with a school or district policy with regards to its membership policy or mission statement.

Though it would be an overstatement to say that the New Consensus addressed all controversies and eradicated all confusion, it can be definitely acknowledged for making a decisive step towards addressing most controversial and confusing issues concerning the place of religion in the public schools. Not only did it prove the constitutionality of religious education, but it went to great lengths to 
show the significance of the inclusion of religious issues in the school curriculum and school life in general. To balance the provisions of the Free Exercise and Establishment Clauses, it advocated teaching about religion as opposed to indoctrination. The guidelines drafted by the New Consensus proponents addressed particular areas of religious expression of students and the school staff.

5. New Consensus and its role in addressing the conflict over the place of religion in the U.S. education system

The consensus proponents believed that case law alone would not enable the communities to live with their deep religious differences. To transform "the battle ground" into "the common ground" they suggested the implementation of the "common ground rules" (Haynes 2001:61-65). They impose the requirement on public schools to make every effort to protect the right of religious liberty for all students and parents. This would primarily involve the inclusion of all sides in taking responsibility to respect and protect the rights of others and to debate differences with civility and respect. Essential to this process is that all sides agree on "three Rs" of religious liberty: rights, responsibilities and respect articulated in the Williamsburg Charter (Haynes 2001:Appendix B). More specifically, working for comprehensive policies, the sides are to put aside labels and stereotypes and take seriously the position of the other side. Working to that end the schools should take a pro-active approach by establishing policies to prepare for potential controversies or conflicts. Finally, the adaptation of a follow-through strategy will ensure that the entire community is kept informed of the religious liberty policies and involved in their implementation through participation in the committee and through periodic public meetings. The New Consensus proponents promoted a new model of school that would operate in compliance with the New Consensus principles, the "civic public school" (Haynes 2001:5). 
6. The official guides devised to facilitate the implementation of the New Consensus ideals in public schools

As articulated in the "common ground rules," reaching agreement on civic principles means little unless the key stakeholders in public education are fully represented in the process of the implementation of the New Consensus ideals and the wider community is informed of the results. This representation should include school officials, teachers and parents as well as local community leaders (Nord and Haynes 1998:29-30). With this intension in mind and to facilitate the efforts of the New Consensus founders, President Clinton directed the Secretary of Education to develop and distribute to every public school superintendent "Religious Expression in Public Schools," the guidelines for religious expression in the public school (U.S. Department of Education 1999). Based upon the earlier "Religion in the Public Schools: A Joint Statement of Current Law" (April, 2005) (American Jewish Congress 1995) and consultation with experts in the field, the guidelines outlined the constitutional and educational role of religion in the public school. They were first released in 1995, and then re-released with very slight alterations in 1998.

In December of 1999 President Clinton asked the Secretary of Education to send out another mailing (Beauchamp 2002).This time it was a set of guidelines and was delivered to every principal in the country. The set included five guides: A Teacher's Guide to Religion in the Public Schools, Public Schools and Religious Communities, A Parent's Guide to Religion in the Public Schools, Religious Expression in Public Schools, How Faith Communities Support Children's Learning in Public Schools. The guides focused on the religious liberty rights of students and teachers, the role of religion in the curriculum as well as the relationship between public schools and religious communities.

The repeated nationwide distribution of the guidelines elevated the New Consensus ideals to a national level. Although it failed to bring the results that would be proportional to its scale, the distribution marked the beginning of some nationwide educational initiatives. One of them is the project First Amendment Schools: Educating for 
Freedom and Responsibility, co-sponsored by the Association for Supervision and Curriculum Development (ASCD) and the First Amendment Center (Haynes 2001:170-173).

The objective of the project was to create laboratories of democratic freedom by providing students and all members of the school community with substantial opportunities to practice democracy. One way in which the principles of freedom and democracy can be upheld is when religious liberty rights are protected. Working to this end, the First Amendment Schools provide all members of the school community with daily opportunities to translate civic education on religious liberty rights into community engagement by addressing problems and issues in their communities. Launched in May 2002, the project presently consists of nearly 100 schools and includes over 70,000 students. This network includes public, private, and charter schools that serve urban, suburban, and rural communities, reflecting the demographic, cultural, and economic diversity of American nation (First Amendment Schools 2014).

As a result of utilizing the New Consensus guidelines to develop their own policies concerning religious liberty, First Amendment School and a number of other schools (Nord and Haynes provide an example of schools in Wicomico County, Maryland; cf. Nord and Haynes 1998:30-32) have seen some positive developments concerning religious liberty issues. On the part of teachers, successful implementation of New Consensus principles emboldened them to take religion seriously in their classroom. Having learned how to implement the rules of rights, responsibility and respect, they engage their religiously diversified students in discussing religious issues on a regular basis. Likewise, students learn that their commitment to religious liberty must be tied to a civic responsibility to guard that right for every citizen, including those they strongly disagree with. They learn how to discuss religious issues in their classrooms without angry arguments about religion that involve name-calling and personal attacks, but with civility and respect (Nord and Haynes 1998:29-30). 
7. Conclusion

The New Consensus was a direct response to the confusion, controversy and the conflict over the place of religion in the US educational system. The confusion and the controversy were largely fuelled by the lack of clear-cut legal regulations as well as the misunderstanding of the Court decision from the 1960s, often wrongly interpreted as rendering religious activity unconstitutional. The public school became a "battle ground" for the opposing sides: the conservatives advocating for reintroduction of religion into the school system and the liberals advocating for keeping religion out. Trapped in the conflict, many school administrators, governing bodies and textbooks publishers, resorted to ridding school from all signs of religious activity. The reports from textbook studies and the curriculum from one side, and the challenges of expanding diversity on the other contributed to the rise of an awareness of prospective dangers of schools being a "naked public square," including the threat it posed to religious liberty.

Alarmed by the reports and motivated by the issue of the "Equal Access Act" and the Williamsburg Charter (Haynes 2001: Appendix B), a number of political and religious institutions and organizations decided to convene to reach a consensus on the most fundamental issues: the constitutionality of teaching religion, its place in the curriculum and the school life, as well as the issue of religious expressions of students and the school officials. Most significantly, the New Consensus proponents agreed that the First Amendment requirement to protect the religious liberty rights of students of all faiths or none involves ensuring that the curriculum includes study about religion, where appropriate, as an important part of a complete education. The New Consensus ideals were further propagated through the guides for teachers and school administrators repeatedly distributed to school administrators throughout the country.

The impact of the New Consensus ideas on the state of religious liberty in the United States public schools is not easy to assess. Although the agreements significantly influenced the national policies about the place of religion in public education, the distribution of 
these ideals did not result in a full nationwide turnabout in approach to religion in schools. Controversy and conflict still abound, extending their reach to embrace some other controversial topics, most notably the issues of sexuality which concern a number of the religious communities. On the other hand, there has been a number of schools where the adaptation of the New Consensus policies and practices has resulted in varying degree of changes for the better: the controversies (of the past) have been largely addressed and conflicts handled in a more civic and respectful manner than in the past, without bitter fights and lawsuits.

\section{Bibliography}

American Jewish Congress, American Ethical Union (1995): Religion in the public schools: a joint statement of current law, April 1995. Available at: <https://www.aclu.org/religion-belief/joint-statement-current-law-religion-publicschools $>$ [Accessed 12 July 2013]

ASCD Panel on Religion in the Curriculum., A. for S. and C.D. (1987): Religion in the curriculum: a report from the ASCD Panel on Religion in the Curriculum. Alexandria, VA.: Association for Supervision and Curriculum Development.

Beauchamp, M. (2002): Guidelines on Religion in Public Schools: A Historic Moment. Available at: <http://rsnonline.org/indexf6db.html?option=com_content\&view=article\&id=688 :guidelines-on-religion-in-public-schools-an-historic-moment\&catid=84:spotlighton-teaching\&Itemid=785> [Accessed 2 July 2013]

Equal Access Act, 20 USC $\S 4071$ - Denial of equal access prohibited. Legal Information Institute. Cornell University Law School. Available at: $<$ http://www.law.cornell.edu/uscode/text/20/4071> [Accessed 27 December 2013]

First Amendment Schools. Project Schools Profiles.[online] Available at: $\langle$ http://www.firstamendmentschools.org/involve/projectprofiles.aspx $>$ [Accessed 24 March 2014]

Haynes, Ch.C. (2001). Finding common ground: a guide to religious liberty in public schools. Nashville, TN: First Amendment Center. Available at: <http://www.freedomforum.org/publications/first/findingcommonground/FCGcomplete.pdf> [Accessed 12 July 2013]

Grudem, W. (1986) Summary of a Book by Paul Vitz Censorship: Evidence of Bias in Our Children's Textbooks. Available at: $<$ http://www.waynegrudem.com/wpcontent/uploads/2012/02/Public-school-textbooks-review-by-Paul-Vitz.pdf> [Accessed 12 July 2013]. 
Lofaso, A.M. (2009). Religion in the public schools: a road map for avoiding lawsuits and respecting parents' legal rights. Washington, D.C: Americans United for Separation of Church and State. Available at: <http://religioninthepublicschools.com> [Accessed 12 July 2013]

Murray, B.T. (2008): Religious liberty in America: the First Amendment in historical and contemporary perspective. Amherst: University of Massachusetts Press in association with Foundation for American Communications.

National Council for the Social Studies (1998). Study About Religions in the Social Studies Curriculum. Available

<http://www.socialstudies.org/positions/religion> [Accessed 9 August 2013]

National Council for the Social Studies. Study About Religions in the Social Studies Curriculum (1998). [online] Available at: <http://www.socialstudies.org/positions/religion> [Accessed 24 March 2014]

Nord, W.A., Haynes Ch.C. (1998): Taking Religion Seriously across the Curriculum. Alexandria, VA: Association for Supervision and Curriculum Development. Available at: 〈http://www.ascd.org/publications/books/198190.aspx > [Accessed 26 August 2013]

President's Memorandum on Religious Expression in Schools. U.S. Government Printing Office. Available at <http://www.gpo.gov/fdsys/pkg/WCPD-1997-0818/html/WCPD-1997-08-18-Pg1246.htm> [Accessed 27 December 2013]

Secretary's Statement on Religious Expression. Department of Education of United States of America. Available at <http://www.lb5.uscourts.gov/ArchivedURLs/Files/09-40373\%281\%29.pdf.> [Accessed 27 December 2013] 